\title{
Comparative growth and welfare in rainbow trout reared in recirculating and flow through rearing systems
}

\author{
Emmanuelle Roque d'Orbcastel ${ }^{a,{ }^{*}}$, Jeanine Person-Le Ruyet ${ }^{b}$, Nicolas Le Bayon ${ }^{b}$ and Jean- \\ Paul Blancheton ${ }^{\mathrm{a}}$
}

\author{
a IFREMER, Station d'Aquaculture Expérimentale, Laboratoire de Recherche Piscicole de Méditerranée. Chemin \\ de Maguelone, 34250 Palavas-les-Flots, France \\ ${ }^{\mathrm{b}}$ UMR 1067 Inra-Ifremer-Bordeaux 1, Ifremer Centre de Brest, BP 70, 29280 Plouzané, France
}

*: Corresponding author : Emmanuelle Roque d'Orbcastel, email address : Emmanuelle.Roque@ifremer.fr

\begin{abstract}
:
The objective of this study was to compare fish performance and welfare at different stocking densities in a recirculating system (RS) and a flow through system (FTS) under field conditions. During the 77 days experiment, the fish survival rate was high (99.3\%) and stocking density increased from 57 to $98-108 \mathrm{~kg} \mathrm{~m}^{-3}$. No significant differences in growth were observed between RS and FTS until day 56 . Later, growth decreased in the FTS, while it remained similar to the farm reference at $50 \mathrm{~kg} \mathrm{~m}^{-3}$ in the RS. Final weight was $17 \%$ higher in RS than in FTS. The maximum carrying capacity of the RS was near $100 \mathrm{~kg} \mathrm{~m}^{-3}$, limited by $\mathrm{NO}_{2}$ increase up to safe level at the end of the experiment, the maximum carrying capacity of the FTS was near $85 \mathrm{~kg} \mathrm{~m}^{-3}$, probably limited by $\mathrm{CO}_{2}$ concentration $\left(17.8 \pm 5.7 \mathrm{mg} \mathrm{l}^{-1}\right)$. In the RS, the relative length index of pectoral and dorsal fins was lower than in the FTS, which may be attributed to the tank hydrodynamics. In both systems, an improvement of the pectoral and dorsal profile was observed at the end of the experiment, attributed to a swimming activity reduction that may have decreased contact between individuals. In the RS, high caudal fin deterioration ( $50 \%$ versus $20 \%$ in FTS) was observed irrespective of stocking density, that could be linked to the highest water velocity modifying the fish swimming activity. The results confirm that when water quality is maintained in safe level ranges, high densities can be used in trout RS without fish performance and pectoral or dorsal fin deterioration, but with a major caudal impairment.
\end{abstract}

Keywords: Recirculating system; Stocking density; Performance; Fin; Welfare 


\section{Introduction}

French trout production is 39000 tonnes per year, with about 800 conventional flow-through farms, operating with stocking densities ranging from 30 to more than $60 \mathrm{~kg} \mathrm{~m}^{-3}$. In flowthrough systems, the water is used only once or twice, with top-up water needs around 100 $\mathrm{m}^{3} \mathrm{~kg}^{-1}$ of feed (Jimenez del Rio et al., 1996; Lemarié et al., 1998). Fish farms are today facing a reduction in available water and deterioration of river water quality. The Water Framework Directive (2000/60) will enforce measures on water consumption and waste discharge. Recirculating systems present the opportunity to reduce water consumption and concomitantly to control water quality. The water treatment loop of recirculating systems allows a 100 fold reduction in top-up water needs. The economic feasibility of recirculating systems has been proved for marine species larval rearing, for broodstock and for ongrowing warm freshwater species (Buckling et al., 1993; Davis and Lock, 1997; Blancheton, 2000; Hinshaw and Thompson, 2000). However, it was not obvious that recirculating systems were competitive for low added value species such as trout (Timmons and Losordo, 1994; Malone, 2002). A few years ago, cost effective recirculating systems were successfully developed in Denmark for trout on-growing, using a simplified water treatment loop and around $10 \mathrm{~m}^{3}$ top-up water $\mathrm{kg}^{-1}$ of feed. There was high interest from a French trout farm in testing such a new recirculating system for rainbow trout on-growing and a pilot system was set up on the farm as part of a program with the Rhône-Méditerranée-Corse Water Agency. It is necessary to increase the production capacity of the recirculating system to divide out the investment costs, by increasing the stocking density. That may lead to water quality deterioration, oxygen reduction and accumulation of fish metabolites, ammonia, $\mathrm{CO}_{2}$ and $\mathrm{NO}_{2}$ and bacterial metabolites. Water quality deterioration generates stress, increases disease susceptibility, affects feed intake and growth and induces an impairment of welfare (Brett, 1979; Piper et al., 1982; Jobling, 1994; Cooke et al., 2000; Ellis et al., 2002).

Ellis et al. (2002) examined 43 studies on the effect of density on rainbow trout welfare. They found that water quality deterioration and/or increase in aggressive behaviour resulting of high stocking density explain most of the negative effects on welfare. Anyway, water quality is the key point for determining the carrying capacity of a culture system, and toxicity thresholds strongly depend on fish species and sizes. For fresh water salmonids, the safe level range of $\mathrm{NH}_{3}$ is large, from 0.002 to $0.025 \mathrm{mg} \mathrm{l}^{-1}$, for TAN long term exposure, the toxicity threshold is around 1-1.5 $\mathrm{mg} \mathrm{N}^{-1}$ (Thurston et al., 1981; US EPA, 1998; Neori et al., 2004; Colt, 2006; Crab et al., 2007); $\mathrm{NO}_{2}-\mathrm{N}$ toxicity threshold is generally around $0.2-0.3 \mathrm{mg}$ $\mathrm{I}^{-1}$ and sometimes lower with $0.1 \mathrm{mg} \mathrm{l}^{-1}$ (Fivelstad et al., 1993). For oxygen, it is 6-7mg. $\mathrm{I}^{-1}$ (Brett, 1979; Pedersen, 1987; Jobling, 1994) and for $\mathrm{CO}_{2}, 10-20 \mathrm{mg} . \mathrm{I}^{-1}$ (Heinen et al., 1996; Fivelstad et al., 1999, 2003).

Fin damage can provide, with other organismic indexes such as mortality rate, relatively simple and rapid indications of health condition under laboratory and farms rearing conditions and also in the wild (Goede and Barton, 1990; Latremouille 2003). Fin condition is considered as an interesting candidate to assess fish welfare that refers to the quality of life or state of well-being of fish (Ellis et al., 2002; Turnbull et al., 2005; Huntingford et al., 2006). Pectoral and dorsal fins are more sensitive than other fins to rearing conditions and can be used as barometers of fish welfare (Pelis and Mc Cormick, 2003). In farms, fin caudal condition is commonly used to sort fish prior to sale.

The objective of our study was to compare fish growth performance and welfare in a recirculating system and a flow through system under field conditions to provide preliminary data relative to a specific request (Murgat farm). Fish welfare was assessed using fin damage descriptors, at the beginning and the end of the experiment, when stocking densities were around 60 and $90 \mathrm{~kg} \mathrm{~m}^{-3}$ respectively. As the experiments were defined and carried out in the frame of a project involving producers, it was decided to implement them at a nearcommercial scale rather than lab scale, in order to provide immediately usable information at the farm level. Because of the near-commercial scale (around 6000 fish, representing almost $10 \%$ of the farm standing stock), it was economically not possible to carry out the 
experiments with replicates. Although fish performance and welfare were studied on a large number of fish which allows a good statistical evaluation. The results found in the recirculating system were also compared to a control in flow through system and to the average results of the commercial scale flow through system of the farm. Those original results are the first published on that type of recirculating system.

\section{Materials and methods}

\section{Biological material}

The study took place in the Murgat farm (Beaurepaire, Isère, France), that produces 600 tonnes per year of brook trout (Salvelinus fontinalis), brown trout (Salmo trutta fario), rainbow trout (Oncorhynchus mykiss) and arctic char (Salvelinus alpinus). The farm is operating in flow through system supplied with high quality well water, stabilised at $12^{\circ} \mathrm{C}$; the average stocking density of the on-growing unit is $50 \mathrm{~kg} \mathrm{~m}^{-3}$.

The experiment started with rainbow trout graded fish, $658 \pm 29 \mathrm{~g}$, from the same population. The 7441 fish were randomly distributed in the two experimental tanks.

Fish performance and welfare were studied on 650-1200 g rainbow trout (Oncorhynchus mykiss), in a recirculating system and a flow through system in parallel, with stocking densities naturally increased from 55 to $100 \mathrm{~kg} \mathrm{~m}^{-3}$ along the experiment in both systems.

Fish were hand fed twice a day, with a commercial diet, Skretting ${ }^{\circledR}, 45 \%$ protein and $28 \%$ lipids. Daily feeding ratio ranged from 0.8 to $1 \%$ of the biomass depending on fish size and temperature, according to the manufacturer's recommendation.

\section{The experimental design}

The adaptability of rainbow trout to grow in a recirculating system (RS) (Roque d'Orbcastel et al., submitted a) was compared to a flow through system (FTS) for 77 days. The tanks of both systems were raceways ( $6 \mathrm{~m}$ wide, $0.65 \mathrm{~m}$ deep). The RS was composed of two of those tanks, side by side, connected at one extremity by a water treatment area (Fig.1). It was divided into a rearing area $\left(70 \mathrm{~m}^{3}\right.$ effective volume) and a treatment unit fitted with two airlifts (for water circulation, oxygenation and $\mathrm{CO}_{2}$ stripping), a sedimentation area and a moving bed filter with plastic media (Roque d'Orbcastel et al., submitted a). The RS was supplied with well water, $7.6 \mathrm{~m}^{3} \mathrm{~kg}^{-1}$ of feed distributed. The FTS (18 $\mathrm{m}^{3}$ effective volume) was used as the reference (Fig. 2). It was supplied with water coming from the first raceways of the farm, after filtration (mechanical drum filter) and oxygenation (low head oxygenator).

Both rearing units were stocked with the same initial density of $57 \mathrm{~kg} \mathrm{~m}^{-3}$ (5859 fish in the RS and 1582 fish in the FTS). The fish number was estimated using a fish counter (HELIOS40, Faivre $\left.{ }^{\circledR}\right)$. The efficiency of the two experimental rearing systems was also compared to the production farm references.

\section{Measured parameters}

The water quality of the two experimental units was followed at the same frequency. $\mathrm{O}_{2}$ and temperature were continuously recorded with SEDIA probes. All other physico-chemical parameters were monitored every other week in outlet water, to identify the limiting factors in the two rearing systems. Water samples were always taken 3 hours after the morning meal. Suspended solid (SS) concentrations were determined after GF/C filtration (AFNOR, NFEN872). Dissolved $\mathrm{N}$ and $\mathrm{P}$ were measured by spectrophotometry. Total ammonia nitrogen $(T A N)$, nitrite nitrogen $\left(\mathrm{NO}_{2}-\mathrm{N}\right)$, urea- $\mathrm{N}$, orthophosphates $\left(\mathrm{PO}_{4}-\mathrm{P}\right)$ were analysed using an Alliance Instruments Evolution II (AFNOR, NFT90015 and ISO, 67771984F). $\mathrm{NH}_{3}$ concentration was calculated using the Johansson and Wedborg (1980) equation according to $\mathrm{pH}$ and temperature values. Nitrate nitrogen $\left(\mathrm{NO}_{3}-\mathrm{N}\right)$ was measured with a Technicon ${ }^{\circledR}$ Autoanalyzer II, after nitrite reduction on a cadmium-copper column (Wood et al., 1970). Total $\mathrm{CO}_{2}$ was measured using an Oxyguard ${ }^{\circledR}$ carbon dioxide portable analyser and $\mathrm{N}_{2}$ with 
the 300 ETM tensionometer ${ }^{\circledR}$. Water velocity was measured using a FLO-MATE ${ }^{\circledR}$ electromagnetic sensor.

Fish mortality was recorded every day. Fish mass increase was estimated every other week by individual weighing of 100 fish fasted for $24 \mathrm{~h}$ for each batch. The specific growth rate (SGR) was calculated as follows:

$S G R=100 *\left(\ln w_{f}-\ln w_{i}\right) *$ number of days ${ }^{-1}$

with wi and wf as the initial and final mean body weight of the fish, respectively.

Fish mass increase in RS and FTS was compared to the farm reference data at $50 \mathrm{~kg} \mathrm{~m}^{-3}$, corresponding to the best rainbow trout performance of the past year. The farm reference growth was not measured during the present study but provided by the farm manager (biometrics done every other week, by global weighing of 100 fish per batch).

The morphology of fish was measured once a month with the Fulton's $\mathrm{K}$ index calculated as followed:

$K=w * 100 * L^{-3} \quad$ with $w=$ weight $(\mathrm{g})$ and $L=$ fork length $(\mathrm{cm})$.

Apparent feed conversion ratio was calculated as total feed distributed per biomass increase according to the method used in the farm.

Fin damage was used as the welfare indicator as described in Person-Le Ruyet et al. (2007). The pectoral and dorsal fins of 50 fish per rearing system were examined at day 15 (D15) and day 69 (D69), when stocking densities were $61.2 \mathrm{~kg} \mathrm{~m}^{-3}$ and $60.7 \mathrm{~kg} \mathrm{~m}^{-3}$ in the RS and FTS respectively (D15), $94.9 \mathrm{~kg} \mathrm{~m}^{-3}$ and $87.9 \mathrm{~kg} \mathrm{~m}^{-3}$ (D69). Fish were anaesthetized (ethylene-glycol-monophenyl-ether, $0.5 \%$ ) before being examined by a same operator. The maximum length of each fin was measured to the nearest $\mathrm{mm}$ to calculate the Relative Length Index (RLI) as follows:

$\mathrm{RLI}=100 \times$ fin length $\mathrm{x}$ fish fork length ${ }^{-1},(\mathrm{~mm}, \mathrm{~mm})$

General fin profile was assessed using five levels of erosion as reported on Fig. 3: Level 0 for a perfect fin and level 4 when all fin rays were eroded.

Erosion level frequency was expressed in percentage and the mean erosion level was calculated.

Caudal fins were also examined and classified in three groups with reference to market index: (A) no marked change in profile in comparison with a perfect caudal fin, excepted minor splits usually observed in farms, (B) moderated erosion with a change in general profile (external fin rays eroded) and (C) major erosion with bleeding or inflamed extremities (not marketable as whole fish). These 3 groups of caudal fins are showed in Fig. 4.

Stumps were not taken into account when resulting from handling stages (net snatching).

\section{Statistical analysis}

Statistics were performed using XLstat ${ }^{\circledR}$. Water quality parameters were compared for two periods, D0-43 and D43-77 using a one-way ANOVA with a fixed effect system. Differences in weight and fin (pectoral and dorsal) damage versus time between RS and FTS were tested using a one-way ANOVA with a fixed effect system. Chi-square test with 5\% significance level was used to investigate the system effect in the caudal erosion frequency.

\section{Results}

\section{Water quality}

During the course of the experiment, well water supply was 20 times lower in RS than FTS and water velocity was 3 times higher $\left(6.1 \pm 0.8 \mathrm{~cm} \mathrm{~s}^{-1}\right.$ in the RS, $2.21 \pm 0.13 \mathrm{~cm} \mathrm{~s}^{-1}$ in the FTS). The well water quality characteristics are presented in Table 1.

There were significant differences between the RS and the FTS water quality and some changes in time were observed after D43. For the period D0-43, SS, NO $\mathrm{N}_{2}-\mathrm{N}, \mathrm{NO}_{3}-\mathrm{N}$ and urea-N concentrations were significantly higher in the RS than in the FTS and conversely TAN concentration was more than twice lower (Table 2). 
From D43, a significant $(P<0.0001)$ increase of TAN, $\mathrm{NO}_{2}-\mathrm{N}$ and $\mathrm{PO}_{4}-\mathrm{P}$ concentrations was observed in the RS, with doubled concentrations in comparison with D0-43. For the D43-77 period, TAN concentration was the same in the RS and FTS (NS difference). Corresponding mean $\mathrm{NH}_{3}$ concentration was $0.0017 \pm 0.0009 \mathrm{mg} \mathrm{l}^{-1}$ in the $\mathrm{RS}$ and $0.0016 \pm 0.0003 \mathrm{mg} \mathrm{l}^{-1}$ in the FTS (maximal concentrations were 0.0033 and $0.0020 \mathrm{mg} \mathrm{l}^{-1}$ ). $\mathrm{NO}_{2}-\mathrm{N}$ concentration in the RS peaked at $0.28 \mathrm{mg} \mathrm{I}^{-1}$ at the end of the experiment and was ten times lower in the FTS.

The $\mathrm{pH}$ and the temperature were similar in the two systems: $\mathrm{pH}$ was $7.33 \pm 0.17$ in the RS and $7.01 \pm 0.29$ in the FTS and average temperature was the same in both systems, $11.6^{\circ} \mathrm{C}$, with higher fluctuations in the RS during the course of the experiment (SE of $1.9^{\circ} \mathrm{C}$ compared to $0.6^{\circ} \mathrm{C}$ in FTS). The $\mathrm{O}_{2}$ outlet concentration was always above $6 \mathrm{mg} \mathrm{l}^{-1}$ in both rearing systems. $\mathrm{CO}_{2}$ concentration was $8.4 \pm 3.1 \mathrm{mg} \mathrm{l}^{-1}$ in the RS and it was twice as high in the FTS, $17.8 \pm 5.7 \mathrm{mg} \mathrm{l}^{-1}$. A $\mathrm{N}_{2}$ super-saturation was observed in the RS, $\mathrm{N}_{2}$ saturation averaged $109.5 \pm 2.5 \%$ during the experiment.

\section{Growth performances}

In both systems, no diseases occurred during the present experiment. Mortality rate was low in both systems, $0.7 \%$, and similar to the farm reference.

The same mass increase was observed in the RS and FTS up to day 56, similar to the mass increase of the farm reference at $50 \mathrm{~kg} \mathrm{~m}^{-3}$. It was followed by a significant decrease in the FTS up to the end of the experiment, corresponding to a stocking density of $84.5 \mathrm{~kg} \mathrm{~m}^{-3}$ in the FTS. In RS, the growth was similar to the farm reference using flow through system and a constant stocking density of $50 \mathrm{~kg} \cdot \mathrm{m}^{-3}$. Stocking density increased progressively from 56 to $108 \mathrm{~kg} \mathrm{~m}^{-3}$ in the RS and from 58 to $98 \mathrm{~kg} \mathrm{~m}^{-3}$ in the FTS (Fig.5 a and b). Days 0-77 SGR was $0.85 \%$ in the RS, compared to $0.68 \%$ in the FTS (farm reference was $0.81 \%$ ). Apparent Feed Conversion Ratio was better in the RS than FTS, 0.97 and 1.17 respectively (farm reference was 1.05). There was no major difference in weight dispersion between the two rearing systems at the end of the experiment (CV, 7.4\% and $8.5 \%$ in RS and $\mathrm{FTS}$ respectively). The $\mathrm{K}$ index was also the same, in both systems, 1.5 .

\section{Welfare status}

RLI of pectoral and dorsal fins were not significantly affected by rearing conditions at D15. Slight differences were observed at D69. RLI was always lower in the RS than in FTS (Table 3).

There were NS differences in mean erosion levels of the 3 fins observed between RS and FTS. An improvement of fin condition was observed at D69 (Table 4).

Pectoral fins were more eroded than dorsal fin. For pectoral fins, the most frequent level was level 2 at D15 (55\% in RS and 65\% in FTS) and level 1 at D69 (i.e. 57 and 64\% in RS and FTS). No intact pectorals were observed and fish with all rays eroded or inflamed extremities were scarce. For dorsal, level 1 was the prevailing frequency, it was higher at D15 than at D69 (Fig.6 a and b).

Caudal condition was significantly lower $(P<0.05)$ in RS than in FTS at D15 and D69, with about $50 \%$ of index C (fish not marketable as whole fish) compared to $20 \%$ in FTS. In both systems level A indexes were lower at D69 (Table 5).

No aggressive behaviour was observed at the different stocking densities tested in the RS. No bite marks and bleeding extremities were observed.

\section{Discussion}

In both systems, water quality was maintained in the range of the safe levels recommended for salmonids. Neither $\mathrm{O}_{2}$ or TAN were closed to unsafe levels: in outlet water, $\mathrm{O}_{2}$ was always above $6 \mathrm{mg} \mathrm{l}^{-1}$ and TAN under $1 \mathrm{mg} \mathrm{l}^{-1}$. The significant differences in most parameters 
observed between the RS and the FTS were mainly explained by the lower water renewal of the RS. Some system specific factors were close to unsafe levels. In the RS, the $\mathrm{NO}_{2}-\mathrm{N}$ concentration increased with the stocking density up to $0.28 \mathrm{mg} \mathrm{l}^{-1}$ at the end of the experiment, close to the trout unsafe level. The $\mathrm{N}_{2}$ was always above the toxicity threshold of $105 \%$ (Hussenot and Leclercq, 1987) but no apparent symptoms of $\mathrm{N}_{2}$ super-saturation, as gas bubble disease, were observed on fish. $\mathrm{N}_{2}$ super-saturation is a well known limiting factor in the airlift system using air injection in depth (Belaud, 1996). In the FTS, $\mathrm{CO}_{2}$ was most often above the 10-20 $\mathrm{mg} \mathrm{l}^{-1}$ safe range (Heinen et al., 1996; Fivelstad et al., 1999, 2003) while it was below $10 \mathrm{mg} \mathrm{l}^{-1}$ in the RS.

In comparison with literature and regular European trout farms data, mortality rate $(0.7 \%)$ was low in both systems; North et al. (2006) found $1.41 \%$ on rainbow trout reared at $80 \mathrm{~kg} \mathrm{~m}^{-}$

${ }^{3}$. Good quality well water can partly explain those results, as well as the strict sanitary rules of the farm (sanitary barrier, special working clothes, control of all inlets...) in addition to a strict farm management.

The best growth results were observed in the RS despite $\mathrm{NO}_{2}-\mathrm{N}$ concentration and $\mathrm{N}_{2}$ supersaturation. They were similar to the farm reference using FTS and stocking density of $50 \mathrm{~kg}$ $\mathrm{m}^{-3}$. In FTS, the causes of growth decrease above $85 \mathrm{~kg} \mathrm{~m}^{-3}$ are unclear. It could be partly explained by long term exposure to a high $\mathrm{CO}_{2}$ concentration $\left(17.8 \mathrm{mg} \mathrm{l}^{-1}\right)$ but a stocking density effect could not be excluded. Under the conditions of the present study, the carrying capacity of the RS for rainbow trout on-growing seems close to $100 \mathrm{~kg} \mathrm{~m}^{-3}$ due to nitrite accumulation, a risk factor for the plastic moving bed (Rusten et al., 2006).

In RS, the relative length index of pectoral and dorsal fin was lower than in FTS and this difference was higher at the end of the experiment. The frequency of highly eroded pectoral and dorsal was below $10 \%$ indicating low profile degradation of these two fins independently of the stocking density. An improvement of the pectoral and dorsal profile seemed to occur by the end of the experiment in both systems. In both systems, marked damages in caudal were observed irrespectively of stocking density; according to the farm's specifications, 20 to $50 \%$ of the fish were not marketable as whole fish.

The decrease of maximum of pectoral and dorsal fin length in RS may be attributed to the RS tank hydrodynamics, with water velocity 3 times higher than in FTS, as reported specially in young salmonid stages (Latremouille, 2003; Pelis and Mc Cormick, 2003; Person-LeRuyet et al., 2007). An impairment of fin condition is generally observed at high stocking density (Ellis et al., 2002). To our knowledge there is no comparison between 60 and $100 \mathrm{~kg}$ $\mathrm{m}^{-3}$ available under rainbow trout farm conditions. A change in fish behaviour was observed during the second part of the experiment. Large fish were calmer, with low swimming activity that may lead to a decrease in contact between individuals and thus reduce fin abrasion. To avoid the relative subjectivity of fin procedure, we worked with a standardized method being used by a single operator to limit any possible bias as discussed in a previous paper (Person Le Ruyet et al., 2007). The high caudal fin deterioration in RS could be attributed to the water velocity that may have modified the fish swimming activity. The water quality in terms of physico-chemical and sanitary parameters may also have impact on caudal condition. In the present experiment, bacterial aspects were not investigated. In the RS, half of the fish should be filleted for sale. The caudal fin is commonly eroded even under the best farming conditions, with high risk of passive aggression during feeding. For these reasons, caudal fin is mainly used as a commercial index and it is more difficult to use as a welfare indicator without a comparison with other fins.

Although fin indexes seemed to be lower in RS than FTS, the performances of the fish (growth and FCR) were better in RS, which confirms the non statistical difference between fin indexes in the two systems.

The maximal carrying capacity of the RS has to be confirmed by further experiments on rainbow trout, after some improvements of tank design specially to limit caudal damage. An optimisation of the water treatment system is also necessary to reduce $\mathrm{N}_{2}$ and $\mathrm{NO}_{2}$ loading.

It will be then interesting to test the modified RS using species which are more sensitive to environmental conditions, such as the brook trout (Salvelinus fontinalis) or the arctic char (Salvelinus alpinus) (Wallace et al., 1988; Baker and Ayles, 1990; Jorgensen et al., 1993). 


\section{Conclusion}

The simplified recirculating system tested for the first time in this French farm appears suitable for rearing large rainbow trout at least up to $100 \mathrm{~kg} \mathrm{~m}^{-3}$. Final stocking density was twice the usual level at the farm, and growth results were better than in FTS. This recirculating system, based on a water supply of $8 \mathrm{~m}^{3} \mathrm{~kg}^{-1}$ of feed, allows a limitation of the water consumption and control of the water quality especially in terms of ammonia and $\mathrm{CO}_{2}$ concentration but an improvement of caudal condition is required. The environmental global analysis of the recirculating system was developed in another publication focussed on Life Cycle Analysis (Roque d'Orbcastel et al., submitted b).

\section{Acknowledgements}

We would like to acknowledge the Rhône-Alpes Water Agency and the Murgat SA for their financial support in the Pilot project and the on-growing farm team, especially Franck Delamarre and Thomas Garsi, for their collaboration during this experiment. 


\section{References}

Baker, R.F., Ayles, G.B., 1990. The effects of varying density and loading level on the growth of Artic Charr (Salvenilus alpinus) and rainbow trout (Oncorhynchus mykiss). World Aquaculture 21, 58-61.

Belaud, A., 1996. Oxygénation de l'eau en aquaculture intensive. Cépaduès Editions, collection Polytech, 207p.

Blancheton, J.P., 2000. Developments in recirculation systems for Mediterranean fish species. Aquacultural Engineering, 22: 17-31.

Brett, J.R., 1979. Environmental factors and growth. In: Hoar, W.S., Randall, D.J., Brett, J.R. (Eds.), Fish Physiology. Bioenergetics and growth, vol. 8. Academic Press, New York, pp. 599-675.

Buckling, R.A., Baird, C.D., Watson, C.A., Chapman, F.A., 1993. Energy use of recycling water aquaculture systems for ornamental fish production. Circular 1095. Florida Cooperative Extension Service. Institute of Food and Agricultural Sciences, University of Florida, Gainesville, FL, 5 pp.

Colt, J., 2006. Water quality requirements for reuse systems. Aquac. Eng. 34, 143-156.

Cooke, S.J., Chandroo, K.P., Beddow, T.A., Moccia, R.D., Mc Kinley, R.S., 2000. Swimming activity and energetic expenditure of captive rainbow trout Oncorhynchus mykiss (Walbaum) estimated by electromyogram telemetry. Aquac. Res. 31, 495-505.

Crab, R., Avnimelech, Y., Defoirdt, T.,Bossier, P.Verstraete, W., 2007. Nitrogen removal techniques in aquaculture for a sustainable production. Aquaculture 270 (2007) 1-14.

Davis, J.T. and J.T. Lock, 1997. Culture of largemouth bass fingerlings. Southern Regional Aquaculture Center (SRAC), Aqua KE Gov Doc, Technical Publication 201, 4pp.

Ellis, T., North, B., Scott, A.P., Bromage, N.R., Porter, M., Gadd, D., 2002. The relationships between stocking density and welfare in farmed rainbow trout. Review paper. J. Fish Biol., 61, 493-531.

Fivelstad, S., Kallevik, H., Iversen, H. M., Møretrø, T., Våge, K., and Binde, M. 1993, Sublethal effects of ammonia in soft water on Atlantic salmon smolts at a low temperature. Aquacult.Int., 1, 157-169.

Fivelstad, S., Olsen, A. B., Kløften, H., Ski, H., W., Stefansson, S., 1999. Effects of carbon dioxide for Atlantic salmon (Salmo salar L.) smolts at constant pH in bicarbonate rich freshwater. Aquaculture, 178, 171-187.

Fivelstad, S., Olsen, A., Åsgård, T., Bæverfjord, G., Rasmussen, T., Vindheim, T. Stefansson, S.O., 2003, Long-term sub-lethal effects of carbon dioxide on Atlantic salmon smolts: ion regulation, haematology, element composition, nephrocalcinosis and growth parameters. Aquaculture, 215, 301-319.

Goede, R.W., Barton, B.A., 1990. Organismic indices and an autopsy-based assessment as indicators of health and condition of fish. Am. Fish. Soc. Symp. 8: 91-108.

Heinen, J.M., Hankins, J.A., Weber, A.L., Watten, B.J., 1996. A semi-closed recirculating water system for high density culture of rainbow trout. Prog. Fish Cult. 58: 11-22.

Hinshaw,J.M.,Thompson,S.L.,2000.Trout Production. Handling Eggs and Fry. Southern Regional Aquaculture Center (SRAC), Aqua KE Gov Doc, Technical Publication 220, 4pp.

Huntingford, F., Adams, C., Braithwaite, V.A., Kadri, S., Pottinger, T.G., Sandoe, P., Turnbull, J., 2006. Current issues in fish welfare. J. Fish Biol., 68, 332-372.

Hussenot, J., Leclercq, D., 1987. La sursaturation des gaz dissous, un phénomène souvent mal connu en aquaculture. Aquarevue 11, 27-31.

Jimenez del Rio, M., Ramazanov, Z., Garcia-Reina, G., 1996. Ulva rigida (Ulvales, Chlorophyta) tank culture as biofilters for dissolved inorganic nitrogen from fishpond effluents. Hydrobiologia, 326-327, 61-66.

Jobling, M., 1994. Fish Bioenergetics. Chapman and Hall, London. 309 pp.

Johansson O., Wedborg, M., 1980. The ammonia-ammonium equilibrium in seawater at temperatures between 5 and $25^{\circ} \mathrm{C}$. J. Solut. Chem. 9, 37-44. 
Jorgensen E.H., Christiansen J.S., Jobling M., 1993. Effects of stocking density on food intake, growth performance and oxygen consumption in artic charr (Salvenius alpinus). Aquaculture, 110, 191-204.

Latremouille D.N., 2003. Fin erosion in aquaculture and natural environments. Rev. Fish. Sci. 11, 315-335.

Lemarié, G., Martin, J. L. M, Dutto G., Garidou, C., 1998. Nitrogenous and phosphorous waste production in a flow-through land-based farm of European seabass (Dicentrarchus labrax). Aquatic Living Resources 11, 247-254.

Malone, R.F., 2002. Engineering for a responsible aquaculture with focus on grow out facilities for commodity finfish. In: Creswell, R.L., Flos, R. (Eds.), Perspectives on Responsible Aquaculture for the New Millennium, World Aquaculture Society, Baton Rouge, LA, USA/The European Aquaculture Society, Oostende, Belgium, pp. 94-111.

Neori, A., Chopin, T., Troell, M., Buschmann, A.H., Kraemer, G.P., Halling, C., Shpigel, M., Yarish, C., 2004. Integrated aquaculture: rationale, evolution and state of the art emphasizing seaweed biofiltration in modern mariculture. Aquaculture 231, 361-391.

North, B.P., Turnbull, J.F., Ellis, T., M.J. Porter, M.J., H. Migaud, H., Bron, J. and N.R. Bromage, 2006. The impact of stocking density on the welfare of rainbow trout (Oncorhynchus mykiss). Aquaculture, 255, 1-4, 466-479.

Pedersen, L.C. 1987, Energy budget for juvenile rainbow trout at various oxygen concentrations. Aquaculture, 62, 289-298.

Pelis R.M., McCormick S.D., 2003, Fin development in stream- and hatchery-reared Atlantic Salmon. Aquaculture 220, 525-536.

Person-Le Ruyet, J., Le Bayon, N., Gros, S., 2007. How to assess fin damage in rainbow trout, Oncorhynchus mykiss ?.Aquat. Living Resour. 20 (2007) 191-195

Piper, R.G., McElwain, LB.. Orme, L.E., McCraren, JR. Fowler. L.G., Leonard, J. R., 1982. Fish hatchery management. U.S. Fish and Wildlife Service, Washington, DC, 517 pp.

Roque d'Orbcastel, E., Blancheton, J.P., Belaud, A., 2009a. Water quality and rainbow trout performance in a Danish Model Farm recirculating system: Comparison with a flow through system. Aquacultural Engineering 40 (2009) 135-143.

Roque d'Orbcastel, E., Blancheton, J.P., Aubin, J., 2009b. Towards environmentally sustainable aquaculture: comparison between two trout farming systems using Life Cycle Assessment. Aquacultural Engineering 40 (2009) 113-119.

Rusten, B., Eikebrokk, B., Ulgenes, Y., Lygren, E., 2006. Design and operations of the Kaldnes moving bed biofilm reactors. Aquacultural Engineering 34, 3 , 322-331

Timmons, M.B., Losordo, T.M., 1994. Aquaculture Water Reuse Systems: Engineering, Design and Management. Elsevier, Amsterdam, The Netherlands, 333 pp.

Thurston, R.V., Phillips, G.R., Russo, R.C., Hinkins, S.M., 1981. Increased toxicity of ammonia to rainbow trout (Salmo gairdneri) resulting from reduced concentrations of dissolved oxygen. Canadian Journal of Fisheries and Aquatic Sciences 38, 983-988.

Turnbull J.F., Bell A., Adams C.E., Bron J., Huntingford F.A., 2005, Stocking density and welfare of cage farmed Atlantic salmon: application of a multivariate analysis. Aquaculture 243, 121-132.

US EPA (United States Environmental Protection Agency), 1998. Update of ambient water quality criteria for ammonia. EPA 822-R-98-008, $148 \mathrm{p}$

Wallace, J.C., Kolbeinshavn, A.G., Reinsnes, T.G., 1988. The effects of stocking density on early growth in Artic charr, Salvelinus alpinus (L.). Aquaculture 73, 101-110.

Wood, JW.1970. Diseases of Pacific Salmon: Their Prevention and Treatment. State of Washington Department of Fisheries, Olympia, WA, USA. 


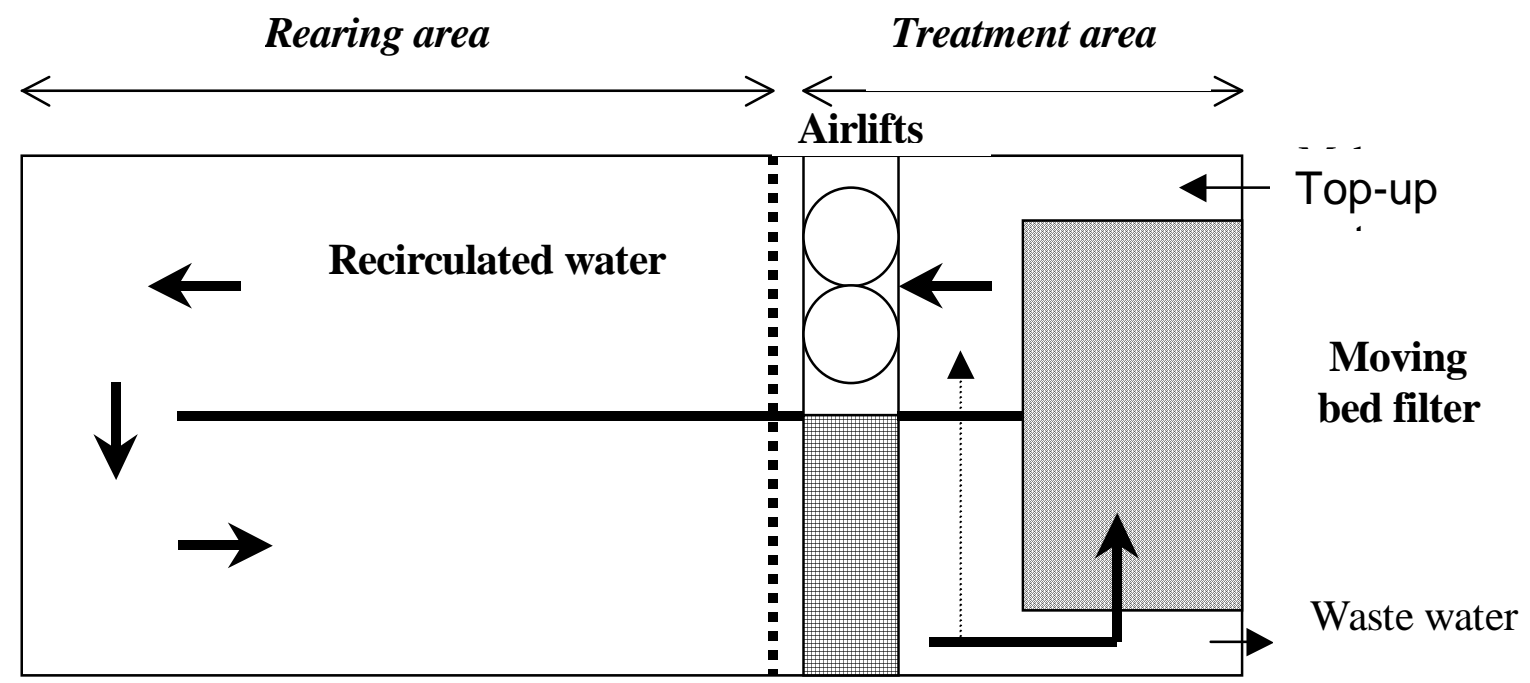

Sedimentation

area

Fig. 1: the experimental recirculating system (RS) (Roque d'Orbcastel et al., submitted a). Water circulation in the RS is represented with thick arrows (in bold), bypass with thin dotted arrow and inlet/outlet waters with thin arrows. Thick dotted lines (in bold) represent the two grids which separate the treatment system (without fish) from the fish rearing area.

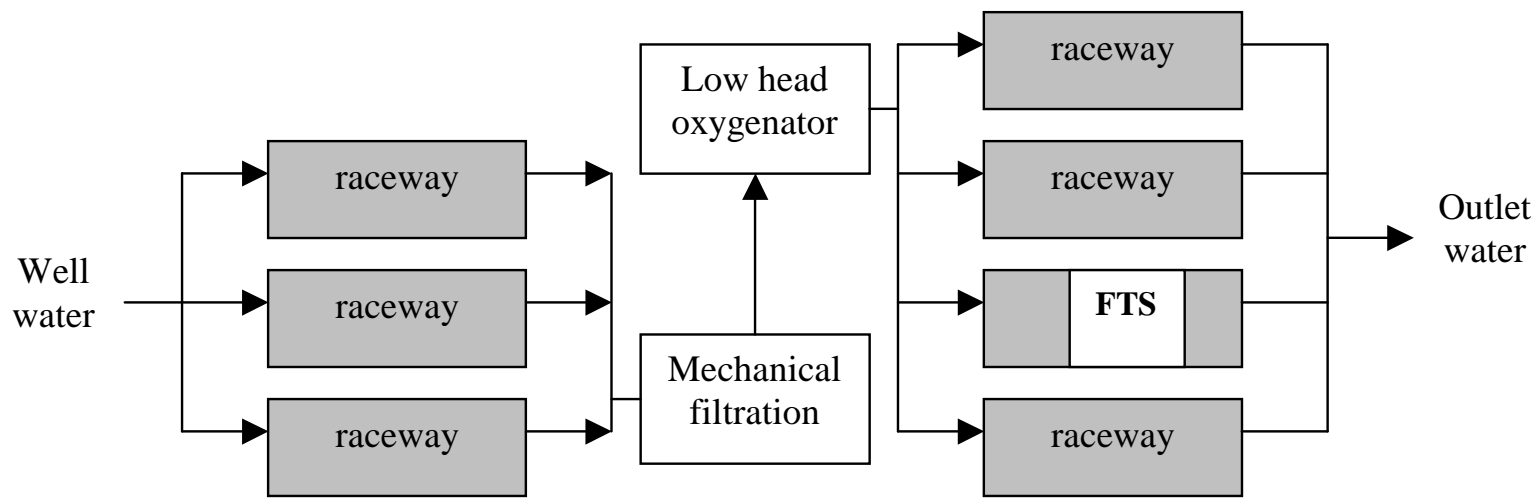

Fig. 2 : the on-growing site and the flow through system (FTS) (Roque d'Orbcastel et al, submitted a) 


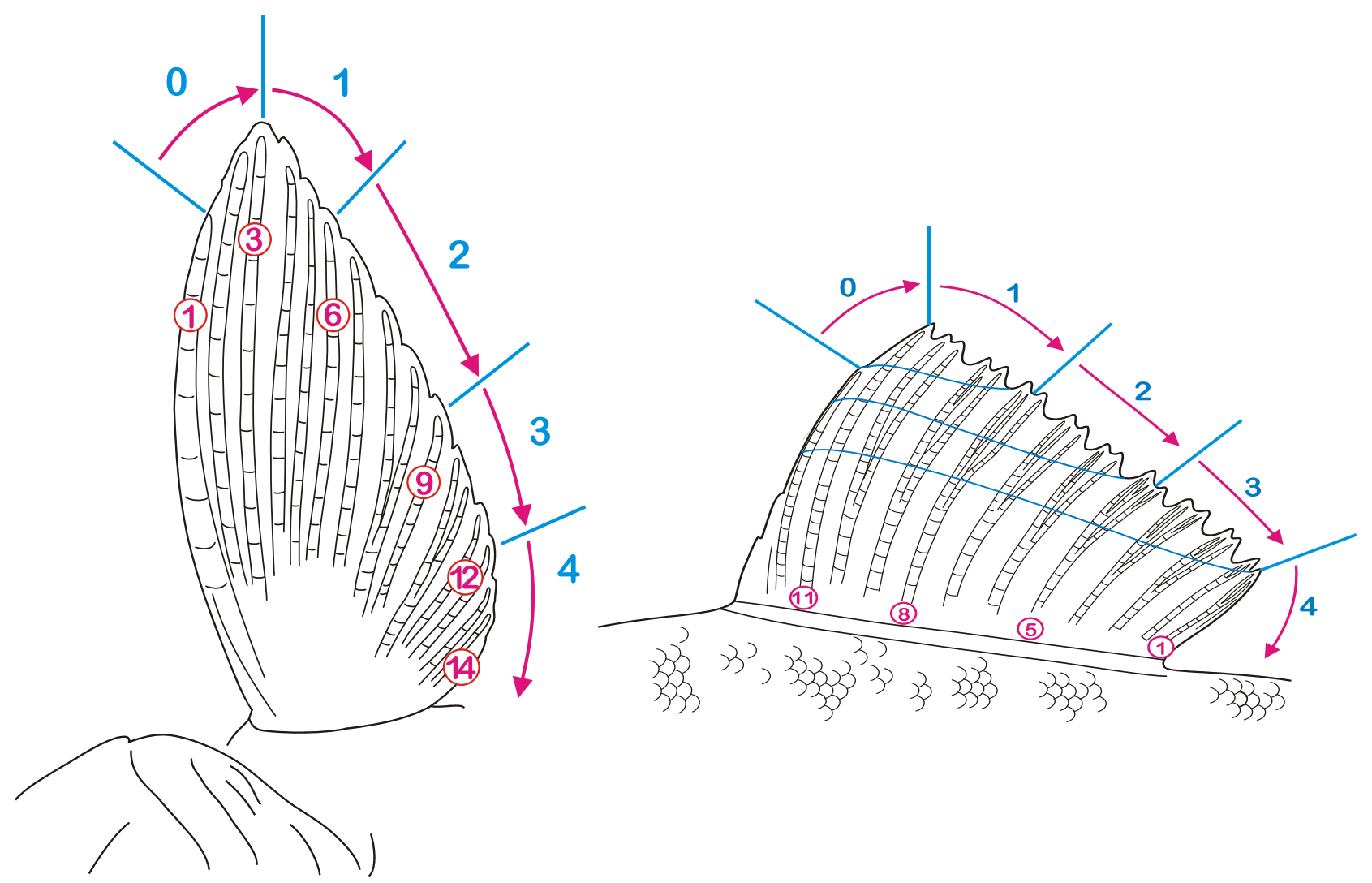

Fig.3. Levels of erosion of dorsal and pectoral fins (after Person Le Ruyet et al., 2007) 


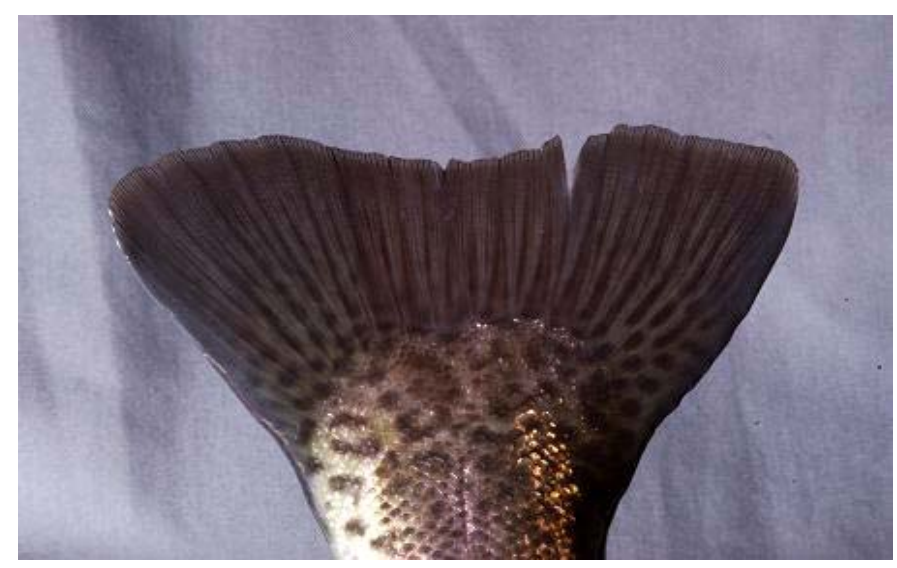

Index A

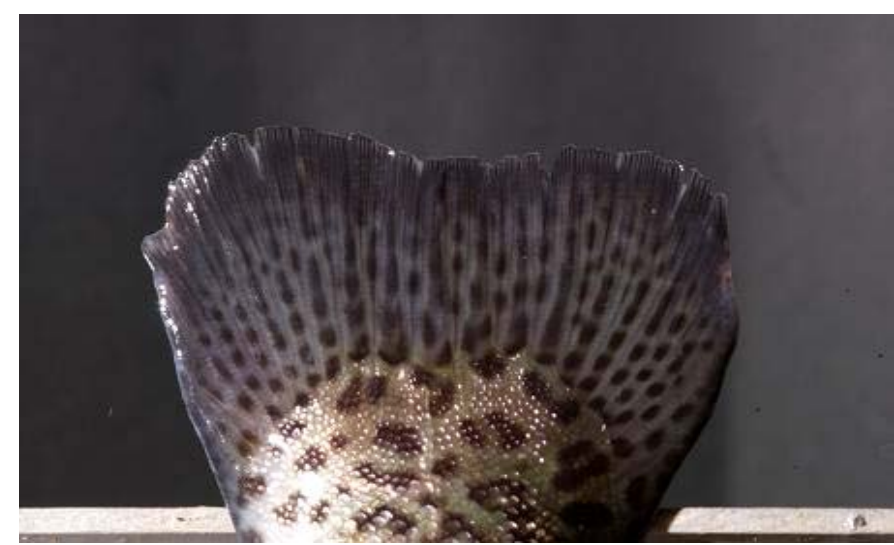

Index B

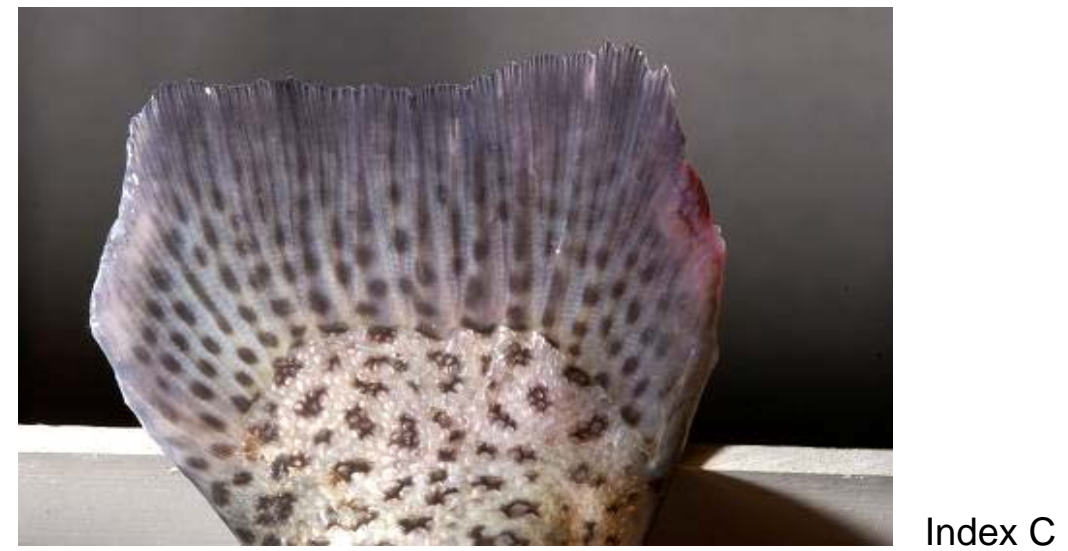

Fig. 4. The three levels of erosion of the caudal fin 

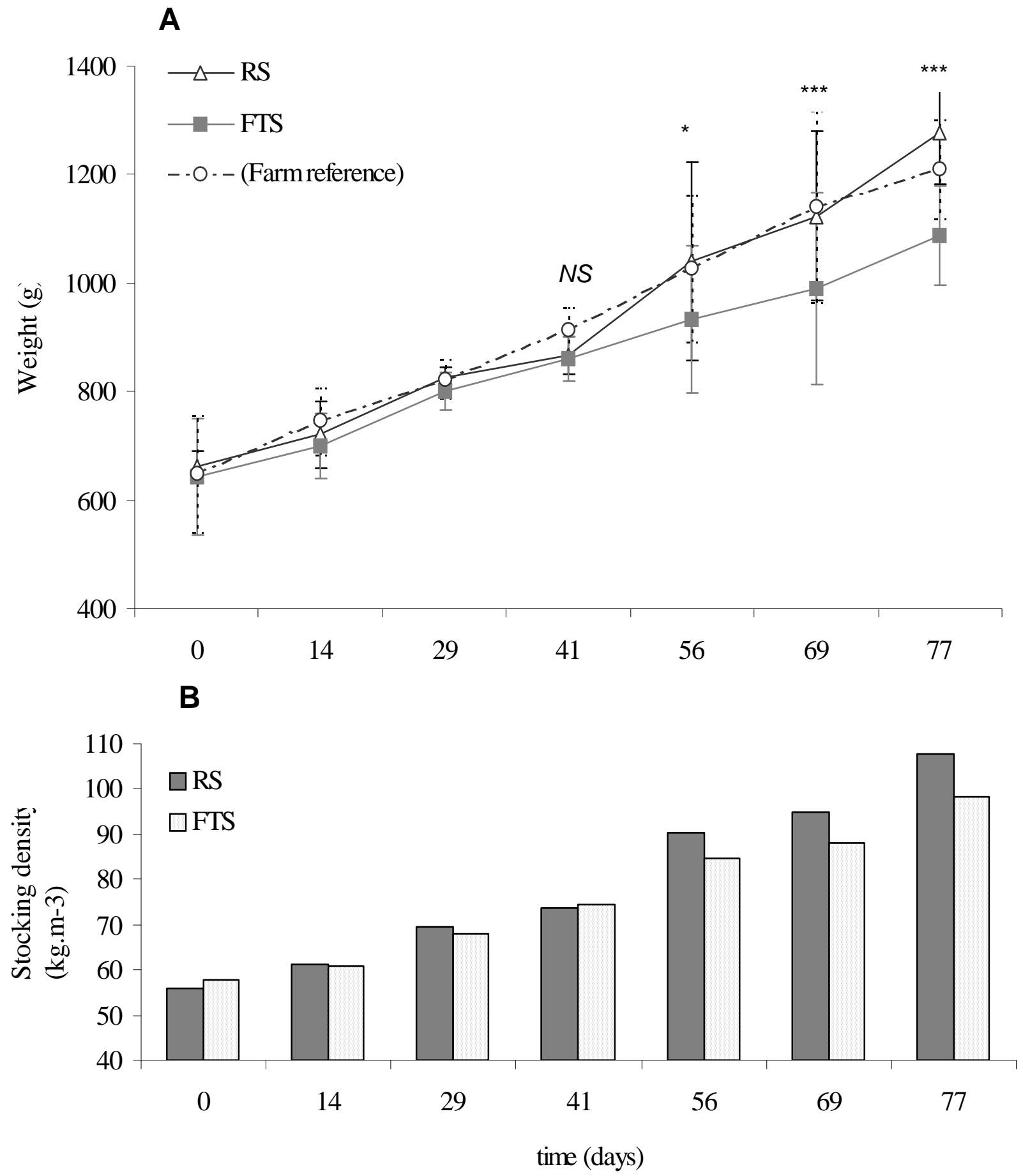

Fig. 5. Changes with time in (A) fish individual weight (mean $\pm S E$ ) in RS and FTS and (B) in stocking density in RS and FTS. For fish growth (A), the farm reference at $50 \mathrm{~kg} \cdot \mathrm{m}^{-3}$ is also showed, for rainbow trout species. Statistical results are given for RS and FTS growth : NS = non significant difference $(P>0.05)$ and ${ }^{*}$ or ${ }^{\star \star *}=$ significant difference $(P<0.05$ and $P<0.001$ respectively). 

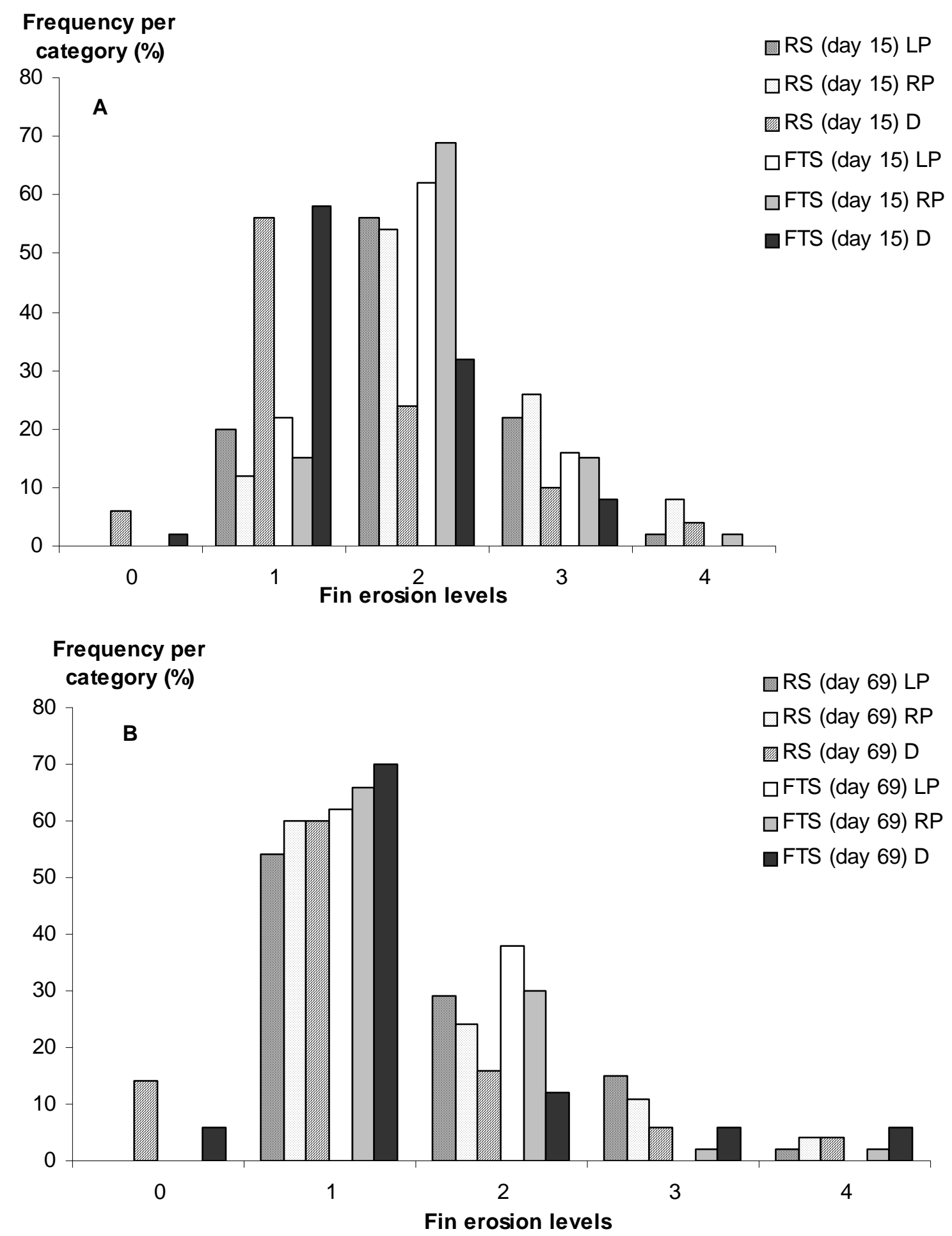

Fig 6. Changes with time (A: at day 15, B: at day 69 ) of erosion levels frequency of right (RP) and left (LP) pectoral fins and dorsal (D) fins in RS and FTS. Erosion level frequency is given in $\%$. 
Table 1. RS inlet water physico-chemical quality $(\mathrm{N}=9)$

\begin{tabular}{|c|c|c|c|c|c|c|c|c|c|}
\hline & $\mathrm{pH}$ & $\begin{array}{c}\text { Temperatur } \\
\text { e }\end{array}$ & $\mathrm{O}_{2}$ & SS & TAN & $\mathrm{PO}_{4}-\mathrm{P}$ & Urea-N & $\mathrm{NO}_{2}-\mathrm{N}$ & $\mathrm{NO}_{3}-\mathrm{N}$ \\
\hline & & ${ }^{\circ} \mathrm{C}$ & \multicolumn{7}{|c|}{ Concentrations in $\mathrm{mg} \mathrm{l}^{-1}$} \\
\hline Mean value & 7.13 & 12.0 & 8.0 & 1.8 & 0.01 & 0.02 & 0.02 & 0.00 & 6.76 \\
\hline$S D$ & 0.39 & 0.7 & 0.9 & 2.4 & 0.01 & 0.05 & 0.02 & 0.00 & 1.51 \\
\hline
\end{tabular}

Table 2. Physico-chemical parameters of tank outlet waters (NS $=$ non significant difference, $\mathrm{P}>0.05$; significant difference : ${ }^{*}=\mathrm{P}<0.05,{ }^{* *}=\mathrm{P}<0.01$ and $\left.{ }^{* *}=\mathrm{P}>0.001\right)(\mathrm{N}=9)$

\begin{tabular}{|c|c|c|c|c|c|c|c|}
\hline 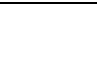 & Period & SS & TAN & $\mathrm{NO}_{2}-\mathrm{N}$ & $\mathrm{NO}_{3}-\mathrm{N}$ & Urea-N & $\mathrm{PO}_{4}-\mathrm{P}$ \\
\hline & & \multicolumn{6}{|c|}{ Concentrations in $\mathrm{mg} \mathrm{l}^{-1}$} \\
\hline RS & \multirow{3}{*}{ D0-43 } & \multicolumn{3}{|c|}{$12.1 \pm 1.50 .24 \pm 0.080 .14 \pm 0.03$} & $9.4 \pm 0.8$ & $\begin{array}{c}0.10 \pm \\
0.05\end{array}$ & $\begin{array}{c}0.05 \pm \\
0.04\end{array}$ \\
\hline FTS & & $6.9 \pm 3.7$ & $0.78 \pm 0$ & $0.02 \pm 0.00$ & $7.9 \pm 0.2$ & $\begin{array}{c}0.15 \pm \\
0.03\end{array}$ & $\begin{array}{c}0.06 \pm \\
0.01\end{array}$ \\
\hline$P$ & & 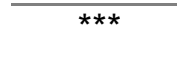 & 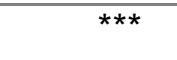 & 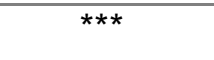 & $\star \star \star *$ & ** & NS \\
\hline RS & & $7.5 \pm 1.4$ & $0.56 \pm 0$. & $0.24 \pm 0.02 \mathrm{c}$ & $9.2 \pm 0.5$ & $\begin{array}{l}0.14 \\
0.03\end{array}$ & $\begin{array}{r} \pm 0.12 \\
0.02\end{array}$ \\
\hline FTS & D43-77 & $1.9 \pm 0.5$ & $0.73 \pm 0$ & $0.02 \pm 0.01$ & $7.6 \pm 0.7$ & $\begin{array}{c}0.15 \pm \\
0.04\end{array}$ & $\begin{array}{c}0.05 \pm \\
0.02\end{array}$ \\
\hline$P$ & & $\star \star \star$ & NS & $\star \star \star$ & $\star \star \star *$ & NS & 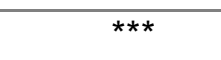 \\
\hline
\end{tabular}

Table 3. Changes with time in RLI of right (RP) and left (LP) pectoral and dorsal (D) fins in RS and FTS - NS, non significant difference $(P>0.05)$; significant difference * $P<0.05$.

\begin{tabular}{lllll}
\hline & Day & LP & RP & D \\
\hline RS $(\mathrm{N}=70)$ & 15 & $9.03 \pm 0.17$ & $8.47 \pm 0.19$ & $7.90 \pm 0.15$ \\
FTS $(\mathrm{N}=70)$ & 15 & $9.28 \pm 0.15$ & $9.24 \pm 0.18$ & $8.01 \pm 0.15$ \\
$P$ & & $N S$ & $N S$ & $N S$ \\
\hline \hline RS $(\mathrm{N}=50)$ & 69 & $8.98 \pm 0.16$ & $8.57 \pm 0.4$ & $7.70 \pm 0.19$ \\
FTS $(\mathrm{N}=50)$ & 69 & $9.65 \pm 0.21$ & $9.35 \pm 0.35$ & $8.29 \pm 0.19$ \\
$P$ & & $*$ & $N S$ & $*$ \\
\hline
\end{tabular}

Table 4. Mean erosion levels of right (RP) and left (LP) pectoral and dorsal (D) fins in RS and FTS - NS, non significant difference $(P>0.05)$.

\begin{tabular}{lllll}
\hline & day & LP & RP & D \\
\hline RS $(\mathrm{N}=70)$ & 15 & $2.06 \pm 0.10$ & $2.30 \pm 0.11$ & $1.50 \pm 0.13$ \\
FTS $(\mathrm{N}=70)$ & 15 & $1.94 \pm 0.09$ & $2.04 \pm 0.09$ & $1.46 \pm 0.10$
\end{tabular}




\begin{tabular}{lllll}
$P$ & & $N S$ & $N S$ & $N S$ \\
\hline \hline RS $(\mathrm{N}=50)$ & 69 & $1.65 \pm 0.12$ & $1.60 \pm 0.13$ & $1.26 \pm 0.13$ \\
FTS $(\mathrm{N}=50)$ & 69 & $1.38 \pm 0.07$ & $1.37 \pm 0.09$ & $1.36 \pm 0.13$ \\
$P$ & & $N S$ & $N S$ & $N S$ \\
\hline
\end{tabular}

Table 5. Changes with time of the frequency of quality indexes of caudal fin in RS and FTS

\begin{tabular}{ccccc}
\hline & day & \multicolumn{3}{c}{ Index frequency (\%) } \\
& & A & B & C \\
\hline RS $(\mathrm{N}=70)$ & 15 & 22 & 32 & 46 \\
FTS $(\mathrm{N}=70)$ & 15 & 56 & 24 & 20 \\
\hline \hline RS $(\mathrm{N}=50)$ & 69 & 0 & 46 & 54 \\
FTS $(\mathrm{N}=50)$ & 69 & 26 & 58 & 16 \\
\hline
\end{tabular}

